www.nature.com/ejhg

\title{
Mitochondrial DNA analysis of the putative heart of Louis XVII, son of Louis XVI and Marie-Antoinette
}

\author{
Els Jehaes ${ }^{*, 1}$, Heidi Pfeiffer ${ }^{2}$, Kaan Toprak ${ }^{2}$, Ronny Decorte ${ }^{1}$, Bernd Brinkmann ${ }^{2}$ and \\ Jean-Jacques Cassiman ${ }^{1}$
}

${ }^{1}$ Center for Human Genetics, University of Leuven, Belgium; ${ }^{2}$ Institüt für Rechtsmedizin, Universität Münster, Germany

According to official historiography, the 10-year-old Louis XVII died in the Temple of Paris on June 8, 1795. However, public rumour spread the theory that Louis XVII escaped and that his descendants would be alive today. One such putative 'Louis XVII' was Carl Wilhelm Naundorff, who died in $\mathbf{1 8 4 5}$ in Delft (the Netherlands). Comparative mitochondrial DNA (mtDNA) analysis gave evidence that his remains could not be identified as those of Louis XVII. In the present study, mtDNA analysis was performed on the heart of the young boy who died in the prison of Paris in 1795. In order to obtain the strongest evidence possible, two laboratories independently analysed the heart. The results showed that the consensus mtDNA sequence of the heart was identical to that of the maternal relatives of Louis XVII. European Journal of Human Genetics (2001) 9, $185-190$.

Keywords: Louis XVII; mitochondrial DNA; ancient DNA; genetic identification

\section{Introduction}

According to official historiography Louis XVII died of tuberculosis in the Temple of Paris during the French Revolution on June 8, 1795. Since then, the official version of his death has been repeatedly questioned. One of the most persistent theories claims that it was a substitute who died, while Louis-Charles escaped out of France. At the beginning of the 19th century a number of men came forward claiming to be the son of Louis XVI. One of these was Karl Wilhelm Naundorff, buried in the Netherlands. DNA analysis showed that the remains of Naundorff could not be identified as those of Louis XVII. ${ }^{1}$ This conclusion was based in the first place on a comparative mtDNA analysis of Naundorff's bone and DNA samples of two living maternal relatives of Louis XVII, Queen Anna of Romania and her brother André de Bourbon-Parme (Figure 1). Furthermore, DNA analysis of hair samples of other maternal relatives, ie two aunts of Louis

${ }^{*}$ Correspondence: Dr Els Jehaes, Center for Human Genetics, Campus Gasthuisberg, O\&N Herestraat 49, B-3000 Leuven, Belgium.

Tel: +32 163458 60; Fax: +32 163459 97;

E-mail: Els.Jehaes@med.kuleuven.ac.be

Received 8 June 2000; revised 18 September 2000; accepted 26 October 2000
XVII, Johanna-Gabriela and Maria-Josepha, and his mother Marie-Antoinette (Figure 1) provided additional proof.

The crucial question of the mystery remained whether really Louis XVII died in the Temple or not. We were asked to perform a mtDNA analysis of the heart of the young boy who died in the Temple on June 8, 1795. The heart was removed by the physician PJ Pelletan during the autopsy and this relic was kept in a crypt at the Basilique Saint-Denis in Paris. Two samples of the heart were taken and independently analysed in two laboratories. The aim was to compare the mtDNA Dloop sequence of the heart with that of the maternal relatives already analysed in the Naundorff case. Some of the results were presented at a press conference in Paris on April 19, 2000. Since then additional results were obtained which do not contradict but strengthen the conclusions presented at the press conference. The full set of data is presented here.

\section{Materials and methods}

Origin and authenticity of the heart of the boy who died in the Temple on June $8,1795^{2}$

In December 1999, a segment of the heart muscle and a piece of the aorta were removed from the heart presumed to be of the boy who died in the Temple on June 8, 1795. 


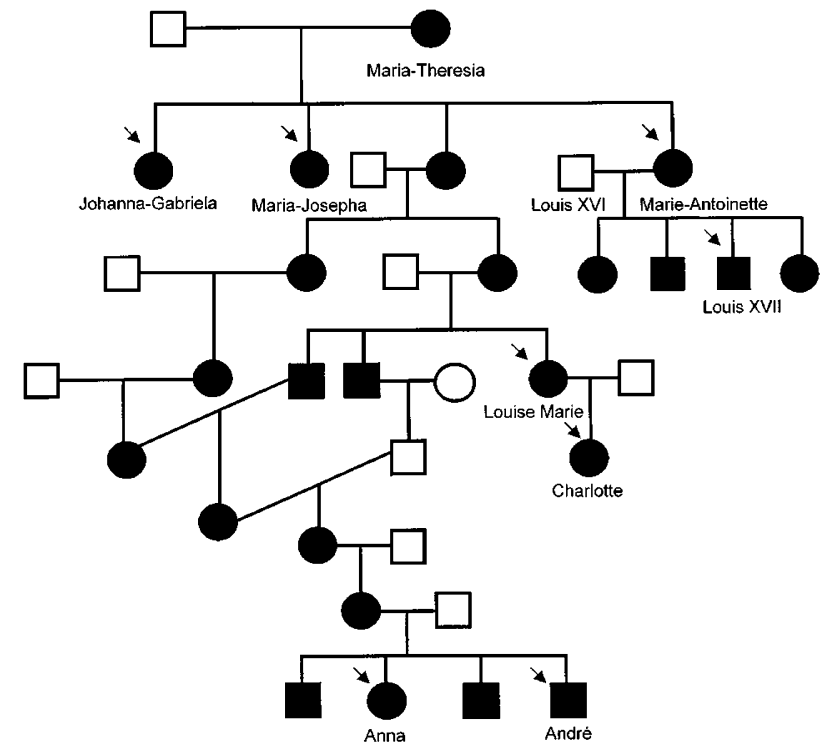

Figure 1 Pedigree of the Habsburg family. The maternal lineages are marked in black. Louis XVII and the maternal relatives analysed in the Naundorff study are indicated by arrows.

After the autopsy, the physician stored the heart in distilled wine alcohol. After 8 to 10 years the alcohol was evaporated and the heart was further kept dry. In 1815, during the Restoration, he offered the relic to Louis XVIII and the Duchesse d'Angoulême, but they refused. Pelletan passed it on to Mgr. De Quélen, archbishop of Paris. After the plundering of the palace in July 1830, the son of Pelletan found the heart in the remains of the palace and put it in a crystal urn in which it is still kept (Figure 2). After his death in 1879, the relic came into the hands of a certain Eduard Dumont. In 1895, the Spanish pretender to the throne Don Carlos de Bourbon accepted the relic. Two of his granddaughters offered the heart to the Duc de Bauffremont, president of the Memorial of Saint-Denis in Paris where he put it in the necropolis of the kings of France.

Public notaries witnessed how two samples were taken from the heart, the transfer, and the opening of the sealed envelopes containing these samples in both laboratories.

\section{DNA extraction and analysis of the mtDNA D-loop (Center for Human Genetics, Leuven)}

From the outset of this study, every effort was made to recover ancient DNA samples free of contamination by contemporary DNA. The same precautions and controls were taken as described in Jehaes et al. ${ }^{1}$ Briefly, all extractions were set up in a dedicated laboratory (where modern DNA had never entered) with dedicated equipment separated from the amplification laboratory. All reagents were filtered through a Microcon 100 (Amicon, Beverly, MA, USA) and negative controls were taken throughout the entire procedure. Guide-

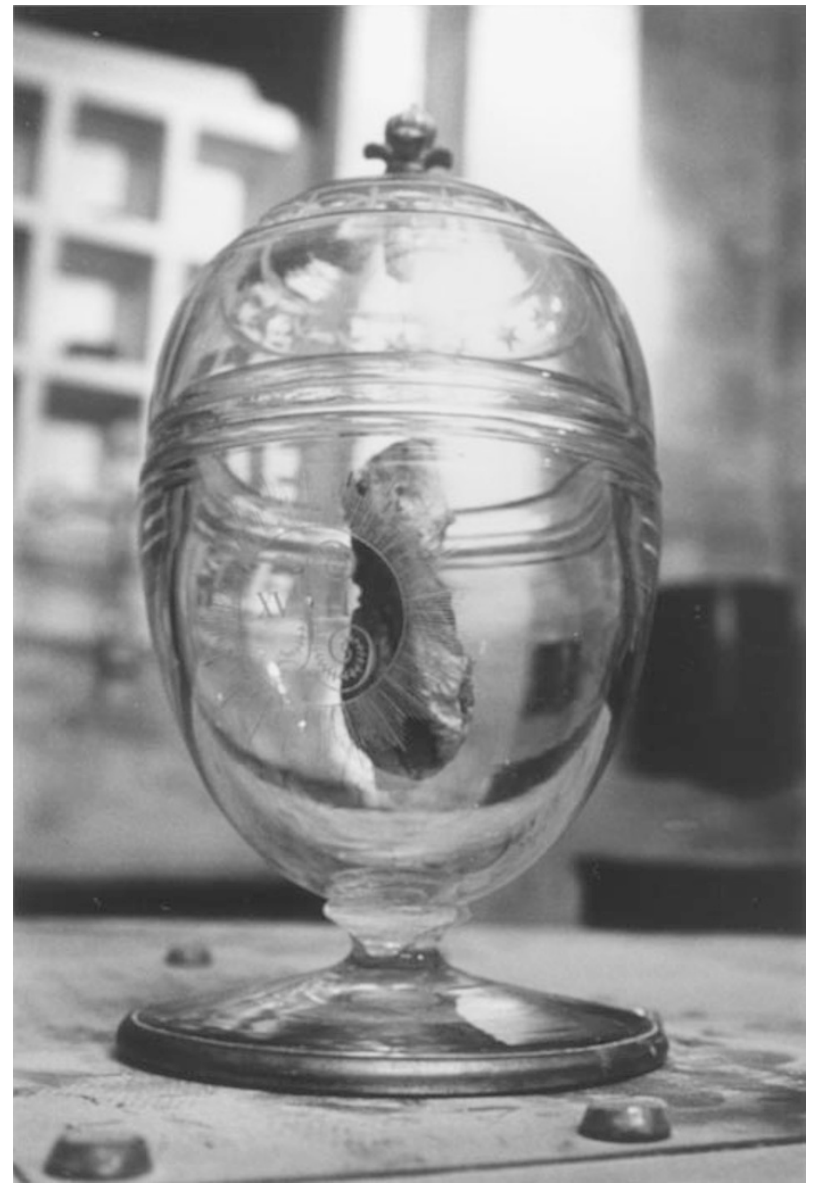

Figure 2 Crystal urn containing the putative heart of Louis XVII, conserved at the Basilique Saint-Denis.

lines were followed as proposed by the DNA commission of the ISFG. ${ }^{3}$

DNA extraction The heart tissue ( $500 \mathrm{mg})$ was divided into five segments: one segment contained a piece of the aorta, the other four segments the heart muscle. The DNA extraction of the five different segments of the heart was done separately on different days. DNA was extracted using the Geneclean for Ancient DNA kit (BIO 101, Vista, CA, USA). The heart tissue was homogenised and incubated overnight in a solution of $1 \mathrm{ml} 0.5 \mathrm{M}$ EDTA, $40 \mu \mathrm{l} 10 \%$ SDS, $40 \mu \mathrm{l}$ $20 \mathrm{mg} / \mathrm{ml}$ Proteinase $\mathrm{K}$ at $37^{\circ} \mathrm{C}$, then processed according to the Geneclean for Ancient DNA protocol. DNA was eluted in $100 \mu$ l elution solution, provided with the kit. For the DNA extraction of the aorta segment a slightly different protocol was used. Aorta tissue was incubated directly in Dehybernation Solution A, provided with the kit, without preincubation in EDTA solution also described in the protocol.

Analysis of the mtDNA D-loop Amplification of two overlapping fragments (between 214 and $293 \mathrm{bp}$ ) for each 
of the two hypervariable regions of the non-coding D-loop was done by a single hot start PCR of 45 cycles using AmpliTaq Gold ${ }^{\mathrm{TM}}$ polymerase (Perkin Elmer, Emeryville, CA, USA) (Jehaes et al., submitted). In addition to the amplification of long fragments, shorter fragments (between 109 and 201 bp) were amplified (Jehaes et al., submitted). The PCR products were directly sequenced according to a solid phase protocol with the Sanger dideoxy chain termination method $^{4}$ on the automated A.L.F. DNA sequencer (Pharmacia Biotech, Uppsala, Sweden).

Detection of an HaeIII restriction site polymorphism A common polymorphism (T-to-C transition) at position 16519 between HV1 and HV2, which creates a HaeIII site was also analysed in the heart DNA extracts as described by Jehaes et al. ${ }^{1}$

Quantification of the number of amplifiable mtDNA molecules for PCR A competitive PCR was used for determination of the number of amplifiable mtDNA molecules for PCR in DNA extracts. ${ }^{5}$ In order to quantify template molecules of different lengths, two primer sets (L16310/ H16401-FITC and L16310/H16526-FITC) were selected to determine the amount of amplifiable fragments with a length of $131 \mathrm{bp}$ and $258 \mathrm{bp}$.

DNA extraction and analysis of the mtDNA D-loop (Institüt für Rechtsmedizin, Münster)

DNA extraction The extractions were carried out with great precaution to avoid contamination. Negative controls were carried along with every extraction and guidelines were followed as proposed by the DNA commission of the ISFG. ${ }^{3}$

The heart tissue $(\sim 500 \mathrm{mg})$ was divided into three fragments and the aorta tissue $(\sim 50 \mathrm{mg}$ ) into two fragments. The DNA extraction of the fragments was performed separately and two different extraction methods were applied.

DNA from one piece of the heart muscle and from the aorta was extracted using the classical phenol-chloroform extraction method ${ }^{6}$ and quantified using the slot-blot method. ${ }^{7}$ The remaining samples underwent a DNA extraction using the NucleoSpin Funnel Columns (Macherey-Nagel, Düren, Germany). The tissues from heart muscle and aorta were cut into small pieces and incubated overnight in a solution of $1 \mathrm{ml}$ buffer T1 provided with the kit and $50 \mu \mathrm{l} 20 \mathrm{mg} / \mathrm{ml}$ Proteinase $\mathrm{K}$ at $56^{\circ} \mathrm{C}$. After complete lysis the extraction was performed according to the Nucleospin $\mathrm{C}+\mathrm{T}$ protocol for the isolation of genomic DNA from cells and tissue. DNA was eluted in $60 \mu$ l elution buffer provided with the kit.

Analysis of the mtDNA D-loop Amplification and sequencing were performed for the whole hypervariable regions HV1 and HV2 as described before. ${ }^{8,9}$ Furthermore, five short overlapping fragments of both regions were investigated. For HV1 the primer pairs L15989/H16175, L16144/H16251 and
L16190/H16410 were used. ${ }^{8,10}$ The short fragments of HV2 were amplified in 35 cycles using primer sets L66/H155 and L88/H252 (Jehaes et al., submitted). DNA sequencing was carried out on an ABI Prism 310 automated sequencer using BigDye Terminator sequencing reagents (ABI-Perkin Elmer, Weiterstadt, Germany). All fragments were sequenced in both directions.

\section{Statistical evaluation}

The significance of the mtDNA match between the heart and a relative of Louis XVII was evaluated by a Bayesian approach. ${ }^{1,11}$ We consider $\mathrm{R}$ that the mtDNA sequence is from Louis XVII or a maternal relative and $\mathrm{R}^{\prime}$ that the mtDNA sequence is from an unknown person. The likelihood ratio (LR) is defined as follows: $L R=p(E \mid R) / p\left(E I R^{\prime}\right)$, where the numerator $\mathrm{p}(\mathrm{E} / \mathrm{R})$ is the probability that the heart belonged to Louis XVII or a maternal relative (no mutation) and the denominator $p\left(E / R^{\prime}\right)$ is the probability that the heart belonged to a random individual. The numerator can be evaluated as $\mathrm{e}^{-\mathrm{gm}}$, where $\mathrm{g}=10$ generational events between Louis XVII and the living maternal descendants or $\mathrm{g}=3$ generational events between Louis XVII and JohannaGabriela, and $m=1 / 33$, the estimated mutation rate of the mtDNA sequence of the D-loop region according to Parsons et al. ${ }^{12}$ The denominator $\mathrm{p}\left(\mathrm{E} \mid \mathrm{R}^{\prime}\right)$ is simply the number of times an identical sequence is obtained in a pairwise database comparison of 941 European mitochondrial DNA sequences (148 Belgians, unpublished data; 100 British; ${ }^{13} 30$ Bulgarians; ${ }^{14} 50$ French; ${ }^{15} 101$ Austrians; ${ }^{16} 358$ Germans; ${ }^{9,17,18} 154$ Swiss ${ }^{19}$ ) which resulted in 1964 identical sequences in 442270 comparisons for positions 16024 to 16365 (HV1) and 73 to 340 (HV2).

\section{Results}

The mtDNA analysis of the heart

At the laboratory in Leuven, DNA was obtained in all five heart segments. Quantification of the number of mtDNA copies surprisingly revealed that the heart contained relatively high amounts of DNA fragments (Table 1). The number of mtDNA copies of a length of 131 nucleotides in the DNA extracts of the heart muscle varied from 1260 to 3750 copies/ $\mu$ l DNA extract and the number of copies of the longer 258 nucleotide fragments varied from 3 to 17 . On the other hand, the number of copies in the aorta extract revealed only 12 copies/ $\mu$ l DNA extract for the short fragments and three for the long fragments.

Sequence analysis of the long PCR fragments in the five different DNA extracts of the heart muscle segment did not always give straightforward results. Since the heart DNA was degraded into small fragments this is not surprising. On the other hand, reproducible sequencing results were obtained for the short PCR fragments. Also, the HaeIII restriction site polymorphism at position 16519 was analysed. For three DNA extracts of the heart muscle, identical mtDNA D-loop 
sequences were obtained which differ in five nucleotide positions from the Anderson reference sequence ${ }^{20}$ (Table 2). In one DNA extract of the heart muscle, the same sequence was also observed but with a minor contamination. The Dloop sequence of the aorta segment also revealed a double sequence at position 152 while position 194 could not be analysed because no DNA extract was left. However, the last two DNA extracts contained less DNA than the others.

At the laboratory in Münster mtDNA could be obtained from all heart tissue fragments with both the following extraction methods.

Phenol-chloroform-extraction Nuclear DNA was found in the heart muscle tissue with a concentration of $0.25 \mathrm{ng} / \mu \mathrm{l}$. The slot-blot quantification of DNA from the aorta extract was negative. mtDNA sequences could be obtained from the heart muscle tissue. The long fragments (whole HV1 and HV2) showed a mixture of two sequences at three positions which could be due to contamination. Therefore the sequencing results of these extracts were not reliable.

Extraction with funnel-columns DNA could be extracted from all pieces of the heart muscle and aorta. The sequencing of the short overlapping fragments gave reproducible,

Table 1 Quantification of mtDNA fragments in the DNA extracts of the heart of the boy who died on June 8, 1795 (Leuven)

\begin{tabular}{|c|c|c|}
\hline \multirow[b]{2}{*}{ Segment } & \multicolumn{2}{|c|}{$\begin{array}{c}\text { Number of copies/ } \mu \text { I DNA extract } \\
+S D\end{array}$} \\
\hline & $131 b p$ & $258 b p$ \\
\hline Aorta & $12 \pm 3$ & $3 \pm 2$ \\
\hline Muscle & & \\
\hline extraction 1 & $1260 \pm 215$ & $17 \pm 6$ \\
\hline extraction 2 & $3262 \pm 499$ & $12 \pm 7$ \\
\hline extraction 3 & $1397 \pm 189$ & $3 \pm 1$ \\
\hline extraction 4 & $3750 \pm 399$ & $10 \pm 2$ \\
\hline
\end{tabular}

SD: standard deviation calculated on five measurements obtained with a dilution series of 500 copies $/ 3 \mu \mathrm{l}$ to 25 copies $/ 3 \mu \mathrm{l}$ of the internal control. identical results (Table 2), whereas the amplification of the long fragments was not successful. The sequences differ in two nucleotide positions from the Anderson reference sequence $^{20}$ (Table 2). The sequencing of the aorta extract was successful only in the two short HV2 fragments.

Based on these results, we could consider the mtDNA Dloop sequence shown in Table 2 as the consensus sequence for the heart.

\section{Comparison of the consensus heart mtDNA sequence with those of maternal relatives of Louis XVII} In order to prove that the heart of the young boy was from Louis XVII, one needs to compare the D-loop sequence of the heart with those of maternal relatives of Louis XVII. The mtDNA sequences of maternal relatives, ie two aunts of Louis XVII (Johanna-Gabriela and Maria-Josepha), his mother, Marie-Antoinette, and two living maternal relatives (Queen Anna of Romania and her brother André) were obtained in the Naundorff study. ${ }^{1}$ The obtained consensus sequence of the heart was identical to the sequence of the living maternal relatives of Louis XVII (Table 3). For the other maternal relatives of Louix XVII there was also a match when HV1 and position 16519 was considered. In the Naundorff study, two nucleotide differences (positions 152 and 194) were found between the mtDNA sequence of the living maternal relatives of Louis XVII and the two aunts and the mother of Louis XVII. ${ }^{1}$ However, the analysis of the mtDNA D-loop of the hair samples of the daughters of Maria-Theresia was performed with long PCR fragments, ie two overlapping fragments of each of the hypervariable regions. It could be, as was observed in the heart sample, that the DNA of the hair was also degraded and that positions 152 and 194 in HV2 were 'missed' because the encompassed amplified fragments were too long. In order to prove this, DNA from two hairs of MarieAntoinette (one of the source of Cannes and one of the source of Nijmegen) and from one hair of Johanna-Gabriela was extracted and analysed with the short PCR fragments. The hair sample of Johanna-Gabriela now showed a mtDNA D-loop identical to the living maternal relatives (Table 3). An even shorter fragment, which encompassed position 194

Table 2 MtDNA D-loop sequences (short PCR fragments) obtained for the heart of the boy who died on June 8, 1795, compared to the Anderson sequence ${ }^{20}$ (Leuven and Münster)

\begin{tabular}{|c|c|c|c|c|c|c|}
\hline & \multirow[t]{2}{*}{$H V 1$} & \multirow{2}{*}{$\begin{array}{l}\text { Haelll gain } \\
\text { T16519 }\end{array}$} & \multicolumn{4}{|c|}{ HV2 } \\
\hline & & & $T 152$ & C194 & $A 263$ & N315.1 \\
\hline \multicolumn{7}{|l|}{ Leuven } \\
\hline Muscle DNA extracts 2,3 and 4 & identical to Anderson & C & C & $\mathrm{T}$ & G & C \\
\hline Muscle DNA extract 1 & identical to Anderson & C & $\mathrm{C}_{(\mathrm{T})}$ & $T_{(C)}$ & G & C \\
\hline Aorta DNA extract & identical to Anderson & $\mathrm{C}_{(\mathrm{T})}$ & $\mathrm{C}_{(\mathrm{T})}$ & NR & G & $\mathrm{C}$ \\
\hline \multicolumn{7}{|l|}{ Münster } \\
\hline Two muscle DNA extracts & identical to Anderson & ND & C & $\mathrm{T}$ & NR & NR \\
\hline Aorta DNA extract & NR & ND & $\mathrm{C}$ & $\mathrm{T}$ & NR & NR \\
\hline Consensus & identical to Anderson & C & C & $\mathrm{T}$ & G & C \\
\hline
\end{tabular}

Nucleotides between brackets are present in minor in the background of the sequence, NR: no results, ND: not determined. 
Table 3 Consensus mtDNA D-loop sequences obtained for the heart of the boy who died on June 8, 1795, and from maternal relatives of Louis XVII, compared to the Anderson sequence ${ }^{20}$

\begin{tabular}{|c|c|c|c|c|c|c|c|}
\hline \multirow[t]{2}{*}{ Origin of sample } & \multirow[t]{2}{*}{ Tissue sample } & \multirow[t]{2}{*}{ HV1 } & \multirow{2}{*}{$\begin{array}{l}\text { Haelll gain } \\
\text { T16519 }\end{array}$} & \multicolumn{4}{|c|}{ HV2 } \\
\hline & & & & $T 152$ & C194 & $A 263$ & N315.1 \\
\hline Louis XVII ? & heart & identical to Anderson & $\mathrm{C}$ & $\mathrm{C}$ & $\mathrm{T}$ & G & $\mathrm{C}$ \\
\hline Johanna-Gabriela* & hair & identical to Anderson & C & C & $\mathrm{T}$ & G & $\mathrm{C}$ \\
\hline Anna** & blood & identical to Anderson & C & C & $\mathrm{T}$ & G & C \\
\hline André ${ }^{* *}$ & hair & Identical to Anderson & ND & C & $\mathrm{T}$ & G & C \\
\hline
\end{tabular}

*New DNA extracts reanalysed after the Naundorff study by short PCR fragments, **analysed in the Naundorff study ${ }^{1}$ ND: not determined.

(from 202 to 117 nucleotides), had to be used not to miss that polymorphism. In the hair of Marie-Antoinette (Nijmegen), a $\mathrm{C}$ at position 152 was also now observed but no polymorphism at position 194, even when a shorter fragment of $117 \mathrm{bp}$ was amplified (Table 3). The second hair of Marie-Antoinette (Cannes) showed multiple ambiguous positions, which indicated contamination.

\section{Discussion}

The results of the mtDNA analysis of the heart show that the heart mtDNA D-loop sequence and the sequence of maternal relatives of Louis XVII are identical. The mtDNA evidence provides strong evidence to support the proposition that the heart was that of Louis XVII. The sequence of the Habsburg family is very unique since it has not yet been observed in a collection of more than 1700 European mtDNA D-loop sequences ${ }^{13}$ (Piercy et al., unpublished results; Peter Forster, personal communication). It is of course impossible, based on these results, to prove that it belonged to the son of Louis XVI and Marie-Antoinette and not to another maternal relative of the Habsburg family. Indeed, only historic data will, in the absence of nuclear markers of the child and his parents, be able to fill this gap. Analysis of the X-Y homologous gene amelogenin resulted in a male sex determination but other nuclear STRs could not be amplified (data not shown). An anatomical report confirmed that the heart belonged to a child between 5 to 12 years.

Based on DNA evidence alone, a likelihood ratio (LR; Bayesian approach, see Materials and methods section) of $166: 1$ is obtained if the living relatives are used as reference, while a LR of 206:1 is obtained when Johanna-Gabriela is considered as the reference. This means that it is 166 (or 206) times more likely that the heart is from a member of the Habsburg family than from an unrelated individual. An upper band for LR would be 1552: 1 if we used the frequency of the mtDNA sequence of the heart $(<1 / 1700)$ in the population and three generational events from JohannaGabriela. This LR might be an underestimate, as the sequence has not been reported before.

Quantification of the number of mtDNA copies surprisingly revealed that the heart contained relatively high amounts of DNA fragments. The fact that in general much more DNA was obtained for the short fragments, compared to long fragments, indicates that the DNA is very degraded but also that authentic DNA was obtained. Indeed, an inverse dependence of the amplification efficiency on the size of the segment to be amplified must exist in ancient DNA extracts. The proportion of the number of copies of $131 \mathrm{bp}$ to the number of copies of $258 \mathrm{bp}$ is 70 to 460 times higher which is very remarkable. It could be that the number of copies of $258 \mathrm{bp}$ is an underestimation because of a polymorphism in the heart DNA in the region where the primer H16526-FITC has to anneal. In order to exclude this, we sequenced this region and found no polymorphism (data not shown). An explanation for the fact that the aorta DNA extract did not contain that many copies of mtDNA compared to the muscle DNA extracts might be that a slightly different extraction protocol was used. However, quantification results of the heart sample investigated in Münster also indicated that the two aorta DNA extracts contained less DNA than the muscle extracts. In the Naundorff study a discrepancy was found between the mtDNA D-loop sequences of the living maternal relatives of Louis XVII and his two aunts and mother. At that time, three possible hypotheses were proposed to explain this discrepancy: (1) the family showed a very high mutation rate; (2) the hairs of the daughters of Maria-Theresia or the obtained sequences were not authentic; or (3) Queen Anna and her brother were the descendants of a female adopted several generations earlier. In view of the irreproducible analysis of long PCR fragments in the ancient heart DNA extracts, new hair DNA extracts of Marie-Antoinette and of one aunt were prepared, which showed that we most probably missed the two nucleotide differences in HV2 and that Johanna-Gabriela matches the living maternal relatives of Louis XVII. For Marie-Antoinette a single nucleotide difference was still found compared to the heart and the maternal relatives of Louis XVII. However, the hairs of Marie-Antoinette were of poor quality and the number of mtDNA copies in the new DNA extract of the hair of MarieAntoinette (Nijmegen) with a length of $131 \mathrm{bp}$ was only two copies/ $\mu$ l DNA extract, and of 258 bp barely one copy/ $\mu$ l. It is clear that DNA typing of living relatives is an absolute necessity in correctly solving historical cases. 


\section{Acknowledgments}

The contribution of Ph. Delorme, French historian, in making this investigation possible by acting as coordinator and by providing the historic background of this mystery is gratefully acknowledged. We are also grateful to the Duc de Bauffremont for authorizing this study and to $H$. Petrie, Dutch historian, for giving us the clue about the existence of the heart. This work was supported by a grant G.0286.00 of the FWO Vlaanderen.

\section{References}

1 Jehaes E, Decorte R, Peneau A et al: Mitochondrial DNA analysis of a putative son of Louis XVI, King of France and MarieAntoinette. Eur J Hum Genet 1998; 6: 383 - 395

2 Delorme P: Louis XVII, La verité: Sa mort au Temple confirmée par la science. Pygmalion, Paris, 2000.

3 Carracedo A, Bär W, Lincoln P, Mayr W et al: DNA commission of the international society for forensic genetics guidelines for mitochondrial typing. Forensic Sci Int 2000; 110: 79-85.

4 Sanger F, Nickle S, Coulson AR: DNA sequencing with chainterminating inhibitors. Proc Natl Acad Sci USA 1977; 74: 5463 5467.

5 Decorte R, Gilissen A, Jehaes E, Cassiman J-J: Determination of the mtDNA content in a human hair by using a quantitative PCR assay; in Olaisen B, Brinkmann B, Lincoln PJ (eds): Progress in Forensic Genetics 7. Elsevier Science BV, 1998, pp 9-11.

6 Sambrook J, Fritsch EF, Maniatis T: Molecular cloning. A new laboratory manual. Cold Spring Harbour Laboratory Press, Cold Spring Harbour New York, 1989.

7 Waye JS, Presley LA, Budowle B, Shutler GG, Fourney RM: A simple and sensitive method for quantifying human genomic DNA in forensic specimen extracts. Biotechniques 1989; 7: 852 855.

8 Holland MM, Fisher DL, Roby RK, Ruderman J, Bryson C, Weed VW: Mitochondrial DNA sequence analysis of human remains. Crime Lab Digest 1995; 22: 109-115.

9 Pfeiffer H, Brinkmann B, Hühne J et al: Expanding the Forensic German mitochondrial DNA control region database: genetic diversity as a function of sample size and microgeography. Int $J$ Legal Med 1999; 112: 291-298.
10 Pfeiffer H, Forster P, Ortmann C, Brinkmann B: The results of an mtDNA study of 1200 inhabitants of a German village in comparison to other Caucasian databases and its relevance for forensic casework. Int J Legal Med 2000; in press.

11 Gill P, Ivanov PL, Kimpton C et al: Identification of the remains of the Romanov family by DNA analysis. Nat Genet 1994; 6: $130-135$.

12 Parsons TJ, Muniec DS, Sullivan K et al: A high observed substitution rate in the human mitochondrial DNA control region. Nat Genet 1997; 15: 363-368.

13 Piercy R, Sullivan KM, Benson N, Gill P: The application of mitochondrial DNA typing to the study of white caucasian identification. Int J Legal Med 1993; 106: 85-90.

14 Calafell F, Underhill P, Tolun A, Angelicheva D, Kalaydjie L: From Asia to Europe: mitochondrial DNA sequence variability in Bulgarians and Turks. Ann Hum Genet 1996; 60: 35 - 49.

15 Rousselet F, Mangin P: Mitochondrial DNA polymorphisms: a study of 50 French Caucasian individuals and application to forensic casework. Int J Legal Med 1998; 111: 292 - 298.

16 Parson W, Parsons TJ, Scheithauer R, Holland MM: Population data for 101 Austrian Caucasian mitochondrial DNA d-loop sequences: Application of mtDNA sequence analysis to a forensic case. Int J Legal Med 1998; 111: 124-132.

17 Baasner A, Schafer C, Junge A, Madea B: Polymorphic sites in human mitochondrial DNA control region sequences: population data and maternal inheritance. Forensic Sci Int 1998; 98: $169-178$.

18 Lutz S, Weisser HJ, Heizmann J, Pollak S: Location and frequency of polymorphic positions in the mtDNA control region of individuals from Germany. Int J Legal Med 1998; 111: $67-77$.

19 Dimo-Simonin N, Grange F, Taroni F, Brandt-Casadevall C, Mangin P: Forensic evaluation of mtDNA in a population from south west Switzerland. Int J Legal Med 2000; 113: 89-97.

20 Anderson S, Bankier AT, Barrel BG et al: Sequence and organization of the human mitochondrial genome. Nature 1981; 290: $457-465$. 